\title{
Building Rejuvenation Approach Through Revitalization, Rehabilitation and Redevelopment - Case of Vertical Housing in Jakarta
}

\author{
Apriansyah Saputra ${ }^{1, *}$, Hendrajaya Isnaeni $^{1}$ \\ ${ }^{1}$ Department of Architecture, Universitas Indonesia, Depok, Indonesia
}

\begin{abstract}
Jakarta, as the center of government, trading, business, and industry becomes the main destination for many migrants to find jobs. This results in the massive population increase in Jakarta every year while the urban area availability has contrast proportion with the needs of housing area. The limited urban area, as well as the increase of land value, is not possible to build new housing area in the city center. The solution of this problem is rejuvenation of the buildings that have already existed. In this case, the writers carry the rejuvenation case of the vertical housing in Kebon Kacang XI that is close to the age limit of the building and has looked slum thus created visibility gap between the vertical housing and the other housing areas and could get the gentrification results. Besides, Kebon Kacang XI vertical housing is located in the center of Jakarta and has increasing BCR so that it is able to maximize the unit of building capacity to fulfill the needs of affordable houses in the city. The aims of this paper are to find out and to compare three different forms of rejuvenation as the solution of housing area provision for the low-income people in the city center through revitalization, rehabilitation, and redevelopment approach.
\end{abstract}

\section{Introduction}

Jakarta is the largest metropolitan city in Indonesia and is also the capital of the Republic of Indonesia which has an area of $661.52 \mathrm{~km} 2$ (sea: $6,977.5 \mathrm{~km} 2$ ), with a population of $10,187,595$ people. Every year, Jakarta's population is always growing due to urbanization and industrialization as well as due to Jakarta's role as a center of government, commerce, business, industry, and providing many jobs. This has resulted in Jakarta being the main destination of migrants to find a job for a better life. Therefore, the population of Jakarta from year to year continues to increase rapidly, while the urban area availability is very limited. It affects the needs of urban facilities including residential facilities which is housing as the primary human needs.

The provision of adequate housing facilities is the responsibility of the state government so that this need can be fulfilled. Nowadays, the government's challenge in meeting the need for decent and affordable housing is quite difficult for the people. This is due to the limited availability of land area. Another obstacle that should not be forgotten is the limited financial ability of the people.

The limited availability of land, the limited financial ability of the people and the very high value of urban land make the low-income people unable to afford residential in the middle of the city and have to be pushed out to the suburban area and result in bringing the city development in an irregular direction known as urban sprawl phenomenon. This phenomenon brings many negative impacts on the city such as causing traffic congestion and air pollution, waste of fuel energy consumption from private vehicle use, and damage to ecosystems caused by diffused and fragmented urban development in open fields [1].

In Jakarta, there are several simple flat houses that have been established for a long time, they are: Rusun Bidara Cina in Jatinegara, Jatibunder Rusun in Tanah Abang, Rusun Karet Tengsin in Tanah Abang, Rusun Apron, Rusun Boing and Rusun Conver in Kemayoran, Rusun Benhil I and II in Tanah Abang, Rusun Menara Marina in Pluit, Rusun Kebon Kacang XI in Tanah Abang. Those flats are government-owned property supporting the housing development program for lowincome people in the center of the city. However, those buildings are averagely over 20 years-old and even some of them aged over 30 years which is almost hit the maximum age limit of a building. The one of those that aged over 30 years is Rusun Kebon Kacang XI.

The structure of flatsKebonKacang XI is approximately 35 years old. The electrical installation in it is 27 years old, whereas normal building is built to last for 30 years [2]. In addition, the Rusun Kebon Kacang $\mathrm{XI}$ is located in the MH. Thamrin which is one of the fastest growing business center areas where the value of

*Corresponding author: aprisaputra190492@gmail.com 
the area's land is constantly increasing and the need to provide shelter close to the business center also increases.

As seen of its appearance, Kebon Kacang XI flat is not feasible compared to the surrounding buildings that have a relatively young age with a modern design. This causes a visibility gap between the tower with other buildings and can lead to gentrification. In addition, the spatial layout in the Kebon Kacang area is very possible to use the high coefficient of building to maximize the capacity of units that can be built in order to meet the needs of affordable housing. Therefore, there is a need for land rejuvenation with a certain approach to restore vitality and optimize the function and capacity of Kebon Kacang XI vertical housing.

\section{Approaches in Building Rejuvenation}

Rejuvenation activities, in a more general sense, are activities involving efforts to rearrange the structure and morphology of the land as a whole. Urban rejuvenation is included in the concept of urban transformation which began in the 19th century where the social, cultural, and economic aspects influenced the physical factors of a city's changes. This is done because the condition of the city began to decline due to the influence of population growth, natural disasters and poor construction [3].

\subsection{Revitalization}

Revitalization arises from the efforts made for empowering an area when the area began to decline due to the abandonment of some of its inhabitants due to the direct influence of the development of economic activities, social pressures, and the impact of new residential development in the suburban areas [4]. In Indonesia, the revitalization of urban areas is regulated in several policies, such as the Minister of Public Works Regulation no. 18 of 2010 on Guidelines for the Revitalization of Regions, Law no. 28/2002 on Building Construction, Minister of Public Works Regulation no. 6 of 2007 on the Building and Environment Plan, and Law No. 11 Year 2011 on Cultural Heritage (UUCB).

The purpose of the revitalization is to cultivate and develop the activity of the regional economy. Afterward, the economic activity is used as activity generator, so that efforts of empowerment, maintenance and strengthening the character of the region can take place well and can revive the activity that ever existed or even complexly restructure the economic activities of the region. In addition to returning the economic value, urban renewal with revitalization approach is usually done to restore the vitality of areas that have historical and cultural value and are conservational. One example is a study conducted by Egercioglu et al. (2015) discusses the conservation project at the historical city center of Tire, Izmir province, Turkey in the context of the scale and dynamics of urban development. They explained that revitalization in the socio-cultural and economic context is a process of urban improvement to eliminate the factors that cause damage or methods to revive the urban areas affected by urban changes. [5]

Tire revitalization needs to be done because of the decline in historical value and regional identity, illegal advertising that is not relevant to the shopping center that destroys the historical identity, the presence of new buildings that are modern and not in accordance with urban culture, decreased the vitality of some buildings and other things that disturbing or incompatible with the culture in Tire.

Another research on revitalization is done by Sharma (2015) which makes revitalization as a city development scenario with the aim of improving the city economy through historic sights in Katra, Jammu and Kasmir, India. Katra is famous for religious pilgrimage tourism, centered on the hill of trikuta where there is a temple where the goddess Vaishno Devi is buried. Every year, there are millions of people visiting the temple [6].

Based on some researches, it is concluded that revitalization is an effort to increase the vitality of urban area through improvement of environmental quality, taking into account the social and cultural aspects of the region.

\subsection{Rehabilitation}

Rehabilitation is an attempt to improve declining area/building performance, which is generally caused by a decrease in the quality environment and aging factors [4]. Rehabilitation is also a rejuvenating mechanism that makes it possible to achieve a sustainable building by utilizing the existing structure [7]. It can be said that a simpler meaning of rehabilitation is "repair", that is to improve maintenance and eliminate damage to an object [8].

In the context of building development, rehabilitation can be carried out in 2 ways, the first is surface rehabilitation, where physical improvements or interventions are only limited to the building's envelope, and in the context of the region generally do not change the physical structure of the area; whereas the second, deep rehabilitation, is an approach with significant physical changes in the area, and in the context of buildings, generally with regard to changes and adjustments made not only to the facade, but to the interior elements, structural systems and construction up to the building utility network also..

\subsection{Redevelopment}

While the meaning of redevelopment is the activity of rebuilding damaged buildings, lands or areas at a high level as a solution to urban problems [9]. Redevelopment is a rejuvenation process characterized by total changes in the physical structure and morphology of urban functional areas (rebuilding) to improve the quality of life, economy, and productivity [4].

Urban rejuvenation refers to a process in which functionally worn out buildings are improved through various methods such as redevelopment, rehabilitation and modernization. But of the many rejuvenation 
methods, redevelopment is the most commonly used method. It also has its own challenges for the government because it requires substantial funds [9].

\section{Building's Life Cycle Stage}

Just like human beings, buildings also have their age and each has life cycle. Buildings have the need for maintenance, repair and renewal of property assets that vary depending on many factors. Although each building has different shapes and structures, it has been determined that many buildings follow the same pattern as they go through different stages in the life cycle of the building. The cycle consists of five commonly identified stages that serve as a reminder to the building owner to anticipate maintenance, repair, and asset update needs. The life cycle of the building is divided into five phases [12] :

- Pre-Natal Phase. It is for less than 1 years old buildings. At this stage the building in the process is handed over from the developer to the first owner. New assets and covered under various guarantees. Treatment requirements are focused on regular cleaning and monitoring activities.

- Childhood phase. It is for 2-16 years old buildings. In this category the owner of the property asset holds full responsibility for the entire maintenance of the building, repairs, and asset updates periodically for a long time. The owner of the property asset allocates a regular budget each year to prevent any possible damage.

- Adolescence phase, is a phase with the age of the building between 17-29 years old. In this period, most likely the project owner can not cover the cost of maintenance due to inadequate budget. The building has almost reached the end of its term to gain profit in the process. The cost of improvements in the building age of this period is increasingly while the incomes from this building is decreased. In this phase, managers and property owners often think of the next strategy to maintain the building's tenure.

- Adulthood phase. It is phase when the buildings have reached age 30-49 years old. At this time, the costs incurred for maintenance and renewal of assets become more massive while the vitality decreases. Some vital parts of building support need to be replaced. At this time property owners and managers may be differentiating on the concept of development.

- Old age phase, with the category of buildings that have reached the age of 50 years. In this phase most assets have reached a maximum lifespan to be replaced, especially the overall finishing elements that need to be totally replaced. While physical buildings such as foundations, concrete floors, columns and roofs can be more durableAuthors should use the forms shown in Table 3 in the final reference list.

\section{Methods}

This study focuses on how a rejuvenation of the building can restore vitality and increase the value of the apartment property of Kebon Kacang as input and advice to the municipality to deal with the problem of providing housing for low-income communities in the city center. With the objective to suggest what kind of appropriate rejuvenation scenario is and see how big the impact will be on changes in economic value and additional space.

To answer that question, the writer who is also a researcher uses mixed method based on Creswell's (2009) theory in his book entitled Research Design of the third edition, mixed method can be used in analyzing a research and is a combination of qualitative methods and quantitative methods where the analysis of mixed methods in the form of text analysis (qualitative analysis) and numerical data (quantitative analysis) [11].

Mixed methods used in analyzing research data are mixed methods with sequential mixed methods. This method is used by combining qualitative and quantitative data to obtain comprehensive analysis results from research problems [11]. The data obtained sequentially from each method and analyzed one by one in turn.

To answer research questions, the writer need three steps of methods. The first step is find the meaning and traits of every form of rejuvenation. The data obtained from previous studies that discuss each cases consisting of building revitalization, rehabilitation and redevelopment. Afterward, the collected data will be analyzed with three steps coding methods (open coding, axial coding, selective coding).

The second step is collecting qualitative data, this study uses primary data obtained from interviews to informants related to research, observation and consumer perception survey by spreading questionnaires addressed to the community who work or have daily activities in Jakarta as the target market of rejuvenated flats.

The interview is addressed to the people who represent the flats that are considered influential to the decision of the residents and will be analyzed with the grounded theory of open coding, axial coding and selective coding to straighten out the result. The questionnaires addressed to the public community to see people's interest and willingness to have and live in lowincome affordable residential in the center of the city but in the form of vertical dwelling. The results of these questionnaires will also determine what appropriate rejuvenation approach is used to the community's interest and willingness as the object of the survey to the rejuvenated Kebon Kacang XI flats.

The third step is to analyze quantitative research data that will strengthen the answer to the first research question as well as to answer the second question, the researcher uses financial investment analysis related to economic factors which will be seen in the calculation

\section{Result and Discussion}

\subsection{Rejuvenation Forms}

Through coding methods, the authors find the understanding of each form of rejuvenation which consists of revitalization, rehabilitation and redevelopment. The words that constitute a code are 
compiled into a sentence which results in the sense that revitalization is an attempt to re-vitalize a land, building or urban by making improvements not only on physical but also non-physical aspects such as economic, social, historical, cultural, environment and economy. Revitalization can be done in various forms such as reconstruction, restoration, conservation, preservation and even rehabilitation and redevelopment. Revitalization can enhance and restore buildings, restore cultural and historical function, preserve heritage architecture, and bred even increase the value of land and buildings.

Rehabilitation is an improvement effort without improving quality and capacity by reusing components and building structures. Rehabilitation may include renovation, restoration, and conservation. Rehabilitation can also be part of revitalization with the aim of maintaining and restoring the historical, cultural, economic and social value of the building for sustainability. While redevelopment is an effort of development and reordering by rebuilding according to the initial function or by changing or increasing the function of buildings that have been damaged. Aims to improve the quality of buildings and increase economic value.

In some cases, the authors found findings that revitalization is a multi-faceted rejuvenation including rehabilitation and redevelopment therein.

\subsection{KebonKacang XI Flats Overview and Location}

At first, Kebon Kacang XI flat was village improvement program initiated by the Jakarta government in 1969 with the aim of improving the environment of the poor in Jakarta [10]. In 1974 the Indonesian government established Perumnas (state-owned housing) to help providing low-cost housing throughout Indonesia. In accordance with the Presidential Instruction, in March 1981 Perumnas was arranged by the Minister of Public Works to begin a new program that would meet lowincome groups in the city. The meant plan was to resettle the urban slum community in the city center into flats on the land they live in. Kebon Kacang was chosen as the venue for the pilot project.

The flats of Kebon Kacang were completed in 1983 and were inhabited in 1984, in an area of 1.2 hectares comprising seven vertical four-story building blocks and 18 to $36 \mathrm{~m} 2$ in size at a price of between IDR 13,000,000 and IDR 16,500,000. The price was a commercial selling price for cross-subsidizing the evicted indigenous people of Kebon Kacang who get the price of IDR 5,000,000, and IDR 8,000,000 at that time.

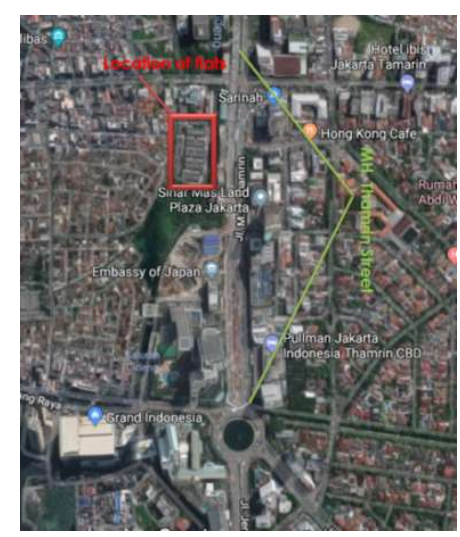

Fig. 1. Location of flats Kebon Kacang XI

As time went by, Kebon Kacang Housing which is located in the area of MH. Thamrin Street, Central Jakarta, began to experience quality degradation. The vertical housing that was originally built to rejuvenate the slum, became rundown and disturbing the scene. Office buildings, embassies, hotels and shopping centers along Thamrin's main road create far discrepancies and differences between the slum houses and the towering buildings surrounding it. Additionally, the value of land in Thamrin has been experiencing a considerable price spike due to its rapid development.

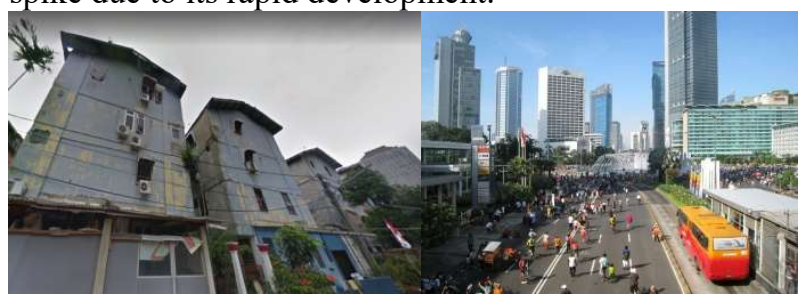

Fig. 2. Physical look of flats Kebon Kacang XI and high rise building on MH. Thamrin Street

Currently, the Kebon Kacang XI flats have already been in the adulthood phase. With the procurement of the rejuvenation program, the flats can be used more efficiently and allow for higher population densities. With the housing inside the denser city, it will reduce the suburban population growth and the traffic congestion caused by the daily commute will be reduced.

\subsection{Perception and Willingness Analysis of Community to Live in Affordable Flats in the Center of City}

Perception and Willingness Analysis of Community to Live in Affordable Flats is an analysis of the response, expectations, and willingness of the public community to live in flats depicted from the percentage of people who agree and the percentage of people do not agree and also associated with the policy plan of rearrangement of Kebon Kacang XI flats. The data were collected through questionnairesdistribution with the required number of samples being at least 96 samples. That numbers were calculated using formula :

$$
\begin{aligned}
& n=\left(\frac{Z \alpha / 2 \cdot \sigma}{e}\right)^{2} \\
& n=\left(\frac{Z \alpha / 2 \cdot p \cdot q}{d}\right)^{2}
\end{aligned}
$$


Information :

$Z \alpha / 2=$ standart value

$\mathrm{n} \quad=$ minimumamount of sample

$\mathrm{p} \quad=$ probability $=0,5$

$\mathrm{q} \quad=1-\mathrm{p}=1-0,5=0,5$

$\mathrm{d} \quad=$ confidence interval $=0,05$

Thus the author believes with $95 \%$ confidence level that 96 samples will give the difference of estimate $\mathrm{x}$ and $\mu$ less than 0.05 . To anticipate the unsuitable data the number of samples added $10 \%$ to 110 samples. However, the data collected by the author amounted to 107 samples.

The questionnaires were spread through online media to the respondent with the target criteria that have been set. The general public criteria that are the target of this respondent are people who have daily work or activity in DKI Jakarta with the aim to see the response and interests of respondents about the provision of affordable house that close to the location of work or the location of their activities everyday. Based on the results of the study of 110 respondents, the phenomenon that occurs shows that $93.4 \%$ of the sample number of people want to have an affordable house close to their work location. But only $66 \%$ of the sample is willing to live in a lowincome community flats.
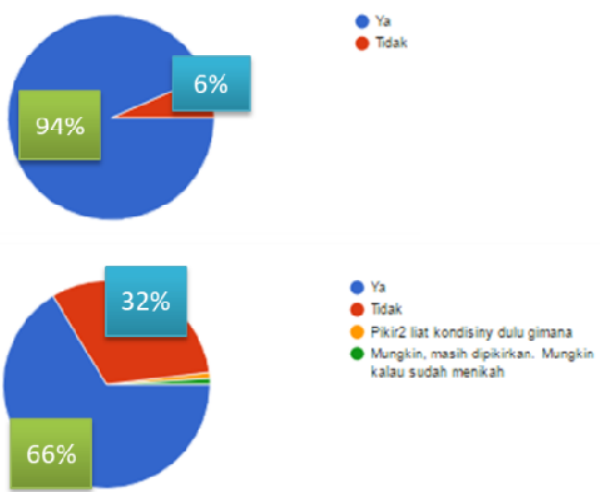

Fig. 3. Percentage of respondents who want to have an affordable house close to their work location and percentage of respondents who willing to live in a low-income community flats.

There are several reasons for deciding to live in Kebon Kacang XI flats. As Daldjoeni pointed out, those location factors are important for income levels. The community will generally try to live near the location of its activities and more emphasis on the economic aspect (Daldjoeni, 1987). This is in accordance with the results of the questionnaire on the travel time variable, most of the respondents traveled (35\%) took less than 25 minutes to the workplace with variable distance between 1 - 5 $\mathrm{km}$. The second rank distance variable is a house that is $5 \mathrm{~km}-10 \mathrm{~km}$ and above $25 \mathrm{~km}$ from the work location $(17 \%)$.

Unit type variable andfacilities variablethat chosen by the respondents will be a guide to the appropriate rejuvenation approach that will be applied based on the public perception as a market of affordable flats that have improved quality. Based on the responses, respondents chose the type 32 to be the most preferred unit $(54.8 \%)$, the second is the type $56(23.8 \%)$, and last type $18(21.4 \%)$.

The most important facilities based on the survey are places of worship because $86.8 \%$ of respondents choose places of worship. The second most selected and the next sequence were park $(82.2 \%)$, parking area $(81.3 \%)$, community hall $(68.2 \%)$, children's play area $(67.3 \%)$, and the last is commercial facilities (61.7\%). However, there are additional answers to the needs of the public that is sports facilities. While based on price variables, $71 \%$ of respondents thought the appropriate price for the flats ranged between Rp 6,000,000 - Rp 7,000,000. With the location, facilities, and cost of interest, as much as $75.7 \%$ of respondents are willing to buy flats and $24.3 \%$ are unwilling.

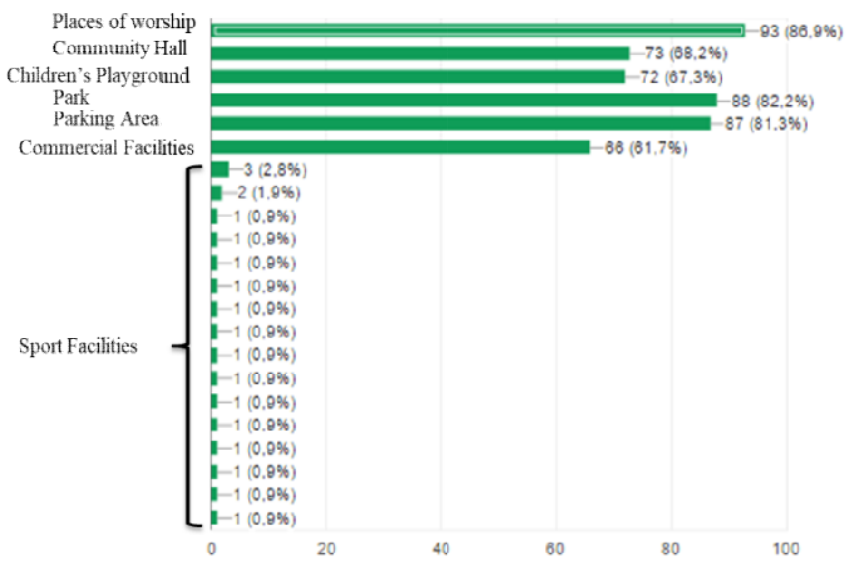

Fig. 4. Most desired facilities based on the survey

\subsection{Perception and Willingness Analysis of Original Residents of Kebon Kacang XI Flats to the Rejuvenation Plan}

The perception data of the residents is obtained from interviews to some of the people who represent the flats that are considered influential to the decision of the residents such as the chairman of hamlet, the chairman of flats governer, the advisor of the Kebon Kacang XI flats and the architect who is also the resident of Kebon Kacang XI.

The result found that there are some problems faced in flats Kebon Kacang XI. It's not just a problem at the age of the building, but also the problems of facilities, occupant, and BRT permits that have been exhausted. In fact, the structure of the tower building is still considered very strong and able to stand up to 50 years. However, for vertical buildings located in areas with BCR $60 \%$ and FAR 4, Kebon Kacang XI flats buildings consisting of only 4 floors is considered wasteful and can still be increased the number of units to increase the availability of affordable housing in the center of the city.

In terms of supporting facilities, flats Kebon Kacang also still have shortcomings. Although there are comfortable mosques as a means of worship, kindergartens, and elementary schools, residents do not have parking space to store their vehicles. As a result, the residents' four-wheeled vehicles were parked along local roads and the courtin the front of the towers that 
were supposed to be the sports facility, and some were parked outside the flats area. In addition, the unavailability of facilities for residents to open a business considering most of the original villagers Kebon Kacang formerly displaced are merchants who work at home. From the interview results, it can be concluded that the residents and prospective residents need supporting facilities such as places of worship, community hall / multipurpose hall, sports facilities, health facilities, commercial facilities, parking lots, and decent building quality.

According to Bambang Prabowo, one of the advisers in Kebon Kacang XI, the rejuvenation desired by the residents of the towers is an improvement of quality. The quality improvement consists of the quality of the building itself and also the occupants quality. In addition to buildings, residents must also experience quality improvement in cleanliness issues, compliance with law, order and living obligations as residents towers. In the Law of the Republic of Indonesia number 20 of 2011, the means of flats quality improvement is rebuilding of flats through demolition, structuring, and development while maintaining ownership rights, including the interests of owners or occupants with due regard to social, cultural and economic factors that are equitable. Improving the quality of the flats is expected to make it feel like a comfortable "home" without losing the value of "kampong" which became the culture of indigenous people of Jakarta.

The Kebon Kacang XI flats rejuvenation program is expected to be guided by Muhammad Husni Thamrin Program (MHT), Integrated Kampung Improvement Program, which focuses not only on improving the basic physical facilities but also more holistic with the concept of Tri Binawith social development, economic development andphysical development [13].

\subsection{Value Increastment Measure with Feasibility Study Simulation}

To strengthen the results of qualitative research, followed by processing the quantitative data obtained from the results of qualitative analysis. These data are the number of flats occupancy based on the interest of the general public, the number of units in each type of flats unit's size, public facilities and social facilities that will be provided along with the design of the building as desired by the original residents and the public community. The data obtained are used in the feasibility study simulation applied to each form of rejuvenation that is revitalization-redevelopment and rehabilitation of buildings. The simulation was conducted to determine the overall increase of the building value to the old building value of two different rejuvenation scenarios.

Based on the calculation result, the revitalizationredevelopment scenario shows a significant increase of the number of units from 530 units to 2332 units and an increase of building value by $87 \%$ while in the rehabilitation scenario there is no increase in the number of units but there is an increase in the value of the flats by $3 \%$.

\section{Conclusion}

This study is a baseline study that attempts to solve the problem of the Kebon Kacang XI flats by determining the appropriate type of building rejuvenation between revitalization, rehabilitation, and redevelopment for the sustainability of housing and meeting the provision of affordable housing for low-income communities in the city. Based on the perception of the general public, the rejuvenation of the flats that the respondents are interested in is rejuvenation with the addition of several facilities such as places of worship, community hall / multipurpose hall, sports facilities, health facilities, commercial facilities, parking lots, and of course decent building quality. As many as $76 \%$ interested in buying a simple apartment in downtown. To fulfill the rearrangement, and to meet the community's need for interest in the provision of flats, redevelopment becomes a suitable rejuvenation approach in rearranging the area and increasing the number of flat units to meet the needs met.

Based on the perception of the original inhabitants, the desired rejuvenation is the one that improves the quality of the flats and does not eliminate the cultural value of the "kampong" in the housing. And also the rejuvenation of the flats not only focus on the physical but also pay attention to social and economic value. So the recommended rejuvenation for the Kebon Kacang XI flats is a combination of revitalization and redevelopment that is rebuilding of flats through demolition, structuring, and development while maintaining and maintaining cultural, social and economic values in it.

\section{References}

[1] A. Frenkel and M. Ashkenazi, "Measuring urban sprawl: how can we deal with it?," Environment and Planning B: Planning and Design, 35, pp. 56$79,(2008)$

[2] Latief, "Kompas.com," 31 May 2016. [Online]. Available:

http://properti.kompas.com/read/2016/05/31/16420 0021/Akademisi.Rusun.Kebon.Kacang.Sudah.Tida k.Layak.Harus.Diperemajaan.. [Accessed 28 December 2017].

[3] A. Sisman and D. Kibaroglu, "Urban Regeneration Application in the world and Turkey," in Turkey Scientific and Technical Congress, Ankara, Turkey, (2009)

[4] W. Martokusumo, "Revitalisasi, Sebuah Pendekatan Dalam Peremajaan Kawasan," Jurnal Perencanaan Wilayah dan Kota, Vol. 19/No. 3, pp. 57 - 73 (2008)

[5] Y. Egercioglu, N. Yakici and T. Ertan, "Urban Decline and Revitalization Project in Izmir-Tire Historical," Urban Planning and Architecture Design for Sustainable Development, UPADSD, pp. 14-16 (2015) 
[6] A. K. Sharma, "Revitalizing the urban development scenario- Contemporary Katra town," Procedia - Social and Behavioral Sciences 216, pp. 236-248 (2016)

[7] C. P. Almeida, A. F. Ramos and J. M. Silva, "Sustainability assessment of building rehabilitation actions in old urban," Sustainable Cities and Society 36, pp. 378-385 (2018)

[8] S. Ognjenovic, R. Ristov and N. Vatin, "Designing of Rehabilitations of Urban and Non-Urban R," Procedia Engineering 117, p. 568 - 573 (2015)

[9] Y. Yau, "Does comprehensive redevelopment change the housing price gradient? A case study in Mongkok, Hong Kong," Urbani Izziv, 22, No. 2, pp. 98 - 106 (2011)

[10] L. Jellinek, The Wheel of fortune : the history of a poor community in Jakarta, North Sydney: Allen \& Unwin Australia (1991)

[11] J. W. Creswell, Research Design: Qualitative, Quantitative, and Mixed Methods Approaches. 3rd ed, (Lincoln: SAGE Publications. Inc, 2009)

[12] Albrice, D. (2015, January 28). Retrieved December 20, 2017, from RDH making Buildings Better: https:/www.rdh.com/long-buildings-last/

[13] Ife, J. Community Development: Alternatif Pengembangan Masyarakat Di Era Globalisasi. Yogyakarta: Pustaka Pelajar. (Yogyakarta: Pustaka Pelajar, 2008) 